\title{
IMPLEMENTASI FUZZY C-MEANS CLUSTERING DALAM PENENTUAN BEASISWA
}

\author{
D. L. Rahakbauw ${ }^{1}$, V. Y. I. Ilwaru' ${ }^{2}$, M. H. Hahury ${ }^{3}$ \\ 1,2,3 Jurusan Matematika FMIPA Universitas Pattimura \\ Jln. Ir. M. Putuhena, Kampus Unpatti, Poka-Ambon, Kode Pos 97233 \\ e-mail: ${ }^{1}$ lodewyik@gmail.com
}

\begin{abstract}
Abstrak
Logika fuzzy merupakan salah satu komponen pembentuk Soft Computing, yaitu suatu cara yang tepat untuk memetakan suatu ruang input ke dalam suatu ruang output. Dalam banyak hal logika fuzzy digunakan sebagai suatu cara untuk memetahkan permasalahan dari input menuju output yang diharapkan. Dalam penelitian ini logika fuzzy digunakan untuk penentuan beasiswa dengan metode Fuzzy C-Means. Untuk mendapatkan beasiswa, ada beberapa kriteria yang harus dipenuhi. Adapun kriteria yang ditetapkan adalah semester, IPK, jumlah tanggungan orang tua, penghasilan total orang tua, dan alat transportasi. Untuk itu diperlukan suatu Sistem Pendukung Keputusan (SPK) yang dapat memperhitungkan segala kriteria yang mendukung pengambilan keputusan guna membantu, mempercepat dan mempermudah proses pengambilan keputusan.
\end{abstract}

Kata Kunci: Beasiswa, Fuzzy C-Means, kriteria, logika fuzzy, SPK

\section{IMPLEMENTATION OF FUZZY C-MEANS CLUSTERING IN SCHOLARSHIP DETERMINATION}

\begin{abstract}
Fuzzy logic is one of the components forming Soft Computing, which is an appropriate way to map an input space into an output space. In many ways fuzzy logic is used as a way to solve problems from inputs to expected outputs. In this research fuzzy logic is used for the determination of scholarship with Fuzzy C-Means method. To get a scholarship, there are several criteria that must be met. The criteria specified are semester, GPA, the number of dependents of parents, parents' total income, and means of transportation. For that required a Decision Support System (SPK) which can take into account all the criteria that support decision-making to help, accelerate and simplify the decision-making process.
\end{abstract}

Keywords: Criteria, Fuzzy logic, Fuzzy C-Means, scholarships, SPK

\section{Pendahuluan}

Beasiswa adalah pemberian berupa bantuan keuangan yang diberikan kepada perorangan yang bertujuan untuk digunakan demi keberlangsungan pendidikan yang ditempuh [1]. Pemberian beasiswa kepada mahasiswa dilakukan secara selektif sesuai dengan jenis beasiswa yang diadakan. Universitas Pattimura menyediakan beberapa program beasiswa, sebagai contoh yaitu beasiswa Peningkatan Prestasi Akademi (PPA), Beasiswa Bantuan Belajar Mahasiswa (BBM), Bidikmisi, dan lain sebagainya. Indeks Prestasi Kumulatif (IPK), jumlah tanggungan keluarga, dan penghasilan total orang tua (penghasilan ayah ditambah penghasilan ibu) menjadi kriteria dalam proses rekruitmen beasiswa. Untuk itu diperlukan suatu Sistem Pendukung Keputusan (SPK) yang dapat memperhitungkan segala kriteria yang mendukung pengambilan keputusan guna membantu, mempercepat dan mempermudah proses pengambilan keputusan.

Proses seleksi penerimaan beasiswa secara manual yaitu dengan menginputkan satu persatu data mahasiswa ke dalam file spreadsheet kemudian melakukan sorting data mahasiswa seringkali menimbulkan beberapa permasalahan, antara lain membutuhkan waktu yang lama dan ketelitian yang tinggi. Selain itu, transparansi serta ketidakjelasan metodologi yang digunakan dalam proses komputasi penerimaan beasiswa 
juga menjadi salah satu permasalahan, sehingga dibutuhkan suatu sistem yang dapat membantu dalam proses pengambilan keputusan siapa saja mahasiswa yang direkomendasikan menerima beasiswa berdasarkan kriteria yang telah ditentukan secara cepat dan tepat sasaran.

Fuzzy clustering adalah salah satu teknik untuk menentukan cluster optimal dalam suatu ruang vektor yang didasarkan pada bentuk normal Euclidean untuk jarak antar vektor. Fuzzy clustering sangat berguna bagi pemodelan fuzzy terutama dalam mengindentifikasi aturan-aturan fuzzy. Ada beberapa algoritma clustering data, salah satu di antaranya adalah Fuzzy C-Means. Fuzzy C-Means adalah suatu teknik pengcluster-an yang mana keberadaannya tiap-tiap titik data dalam suatu cluster ditentukan oleh derajat keanggotaan. Teknik ini pertama kali diperkenalkan oleh Jim Bezdek [2].

Konsep dari Fuzzy C-Means pertama kali adalah menentukan pusat cluster, yang akan menandai lokasi rata-rata untuk tiap-tiap cluster. Pada kondisi awal, pusat cluster ini masih belum akurat. Tiap-tiap titik data memiliki derajat keanggotaan untuk tiap-tiap cluster. Dengan cara memperbaiki pusat cluster dan derajat keanggotaan tiap-tiap titik data secara berulang, maka akan dapat dilihat bahwa pusat cluster akan bergerak menuju lokasi yang tepat. Output dari Fuzzy C-Means merupakan deretan pusat cluster dan beberapa derajat keanggotaan untuk tiap-tiap titik data. Informasi ini dapat digunakan untuk membangun suatu fuzzy inference system. Dalam penelitian ini akan dibahas tentang penentuan beasiswa kepada mahasiswa yang direkomendasikan menerima beasiswa berdasarkan kriteria yang ditentukan dengan menggunakan Fuzzy C-Means Clustering.

\subsection{Logika Fuzzy dan Operasi Himpunan Fuzzy}

Logika fuzzy merupakan seuatu logika yang memiliki nilai kekaburan atau kesamaran (fuzziness) antara benar atau salah. Logika Fuzzy pertama kali diperkenalkan oleh Prof. Lotfi A. Zadeh pada tahun 1965. Dalam teori logika fuzzy suatu nilai bias bernilai benar atau salah secara bersama. Namun berapa besar keberadaan dan kesalahan suatu tergantung pada bobot keanggotaan yang dimilikinya. Logika fuzzy memiliki derajat keanggotaan dalam rentang 0 hingga 1 . Berbeda dengan logika digital yang hanya memiliki dua nilai 1 atau 0. Logika fuzzy digunakan untuk menterjemahkan suatu besaran yang diekspresikan menggunakan bahasa (linguistic), misalkan besaran kecepatan laju kendaraan yang diekspresikan dengan pelan, agak cepat, cepat, dan sangat cepat. Dan logika fuzzy menunjukan sejauh mana suatu nilai itu benar dan sejauh mana suatu nilai itu salah. Tidak seperti logika klasik (crisp)/ tegas, suatu nilai hanya mempunyai 2 kemungkinan yaitu merupakan suatu anggota himpunan atau tidak. Derajat keanggotaan 0 (nol) artinya nilai bukan merupakan anggota himpunan dan 1 (satu) berarti nilai tersebut adalah anggota himpunan.

Logika fuzzy adalah suatu cara yang tepat untuk memetakan suatu ruang input ke dalam suatu ruang output, mempunyai nilai kontinu. Fuzzy dinyatakan dalam derajat dari suatu keanggotaan dan derajat dari kebenaran. Oleh sebab itu sesuatu dapat dikatakan sebagian benar dan sebagian salah pada waktu yang sama [3]. Logika Fuzzy memungkinkan nilai keanggotaan antara 0 dan 1, tingkat keabuan dan juga hitam dan putih, dan dalam bentuk linguistik, konsep tidak pasti seperti "sedikit", "lumayan" dan "sangat".

Pada teori himpunan fuzzy, peranan derajat keanggotaan sebagai penentu keberadaan elemen dalam suatu himpunan sangatlah penting. Nilai keanggotaan atau derajat keanggotaan atau membership function menjadi ciri utama dalam penalaran dengan logika fuzzy tersebut.

Operasi himpunan fuzzy diperlukan untuk proses inferensi dan penalaran. Dalam hal ini yang dioperasikan adalah derajat keanggotaannya. Derajat keanggotaan sebagai hasil dari operasi dua buah himpunan fuzzy disebut sebagai fire strength atau $\alpha$-predikat. Ada beberapa hal yang perlu diketahui dalam memahami sistem fuzzy yaitu:

1) Variabel fuzzy merupakan variabel yang hendak dibahas dalam sistem fuzzy.

2) Himpunan fuzzy merupakan suatu grup yang mewakili suatu kondisi atau suatu keadaan tertentu dalam suatu variabel fuzzy

3) Semesta pembicaraan adalah kesluruhan nilai yang diperbolehkan untuk dioperasikan dalam suatu variabel fuzzy.

4) Domain himpunan fuzzy adalah keseluruhan nilai yang diijinkan dalam semesta pembicaraan dan boleh dioperasikan dalam suatu himpunan fuzzy. 


\subsection{Sistem Pendukung Keputusan}

Sistem Pendukung Keputusan merupakan sistem berbasis komputer yang interaktif, yang membantu pengambil keputusan dengan memanfaatkan data dan model untuk menyelesaikan masalah-masalah yang tak terstruktur [4]. Ada yang mendefinisikan bahwa sistem pendukung keputusan merupakan suatu pendekatan untuk mendukung pengambilan keputusan. Sistem pendukung keputusan menggunakan data, memberikan antarmuka pengguna yang mudah, dan dapat menggabungkan pemikiran pengambil keputusan.

\subsection{Fuzzy C-Means (FCM)}

Fuzzy C-Means Clustering (FCM), atau dikenal juga sebagai Fuzzy Isodata merupakan salah satu metode clustering yang merupakan bagian dari metode Hard K-Means. FCM menggunakan model pengelompokan fuzzy sehingga data dapat menjadi anggota dari semua kelas atau cluster terbentuk dengan derajat atau tingkat keanggotaan yang berbeda antara 0 hingga 1 . Tingkat keberadaan data dalam suatu kelas atau cluster ditentukan oleh derajat keanggotaannya.

Konsep dasar FCM, pertama kali adalah menentukan pusat cluster yang akan menandai lokasi ratarata untuk tiap-tiap cluster. Pada kondisi awal pusat cluster ini masih belu akurat. Tiap-tiap data memiliki derajat keanggotaan untuk tiap-tiap cluster. Dengan cara memperbaiki pusat cluster dan nilai keanggotaan tiap-tiap data secara berulang, maka dapat dilihat bahwa pusat cluster akan menujui lokasi yang tepat. Perulangan ini didasarkan pada minimasi fungsi obyektif yang menggambarkan jarak dari titik data yang diberikan ke pusat cluster yang berbobot oleh derajat keanggotaan titik data tersebut [5].

\subsection{Algoritma FCM}

Fuzzy C-Means Clustering (FCM), atau dikenal juga sebagai fuzzy Isodata merupakan salah satu metode clustering yang merupakan bagian dari metode Hard K-Means. FCM menggunakan model pengelompokan fuzzy sehingga data dapat menjadi anggota dari semua kelas atau cluster terbentuk dengan derajat atau tingkat keanggotaan yang berbeda antara 0 hingga 1 . Tingkat keberadaan data dalam suatu kelas atau cluster ditentukan oleh derajat keanggotaannya.

Algoritma yang digunakan pada metode Fuzzy C-means adalah sebagai berikut:

1) Input data yang akan di-cluster, $X$, berupa matriks berukuran $n \times m$ ( $n=$ jumlah sampel data, $m=$ atribut setiap data). $X_{i j}$ data sampel ke- $i(i=1,2, \cdots, n)$, atribut ke- $j(j=1,2, \cdots, m)$.

2) Tentukan:

- Jumlah cluster $=c$

- Pangkat $=w$

- Maksimum iterasi $=$ Maxlter

- Error terkecil yang diharapkan $=\xi$

- Fungsi objektif awal $=P_{0}=0$

- Iterasi awal $=t=1$

3) Bangkitkan bilangan random $\mu_{i k}, i=1,2, \cdots, n ; k=1,2, \cdots, c$; sebagai elemen-elemen matriks partisi awal $U$.

Hitung jumlah setiap kolom

Hitung:

$$
Q_{i}=\sum_{k=1}^{c} \mu_{i k} \quad \text { dengan } j=1,2, \cdots, n
$$

$$
\mu_{i k}=\frac{\mu_{i k}}{Q_{i}}
$$


4) Hitung pusat cluster ke- $k, V_{k j}$ dengan $k=1,2, \cdots, c$ dan $j=1,2, \cdots, m$

$$
V_{k j}=\frac{\sum_{i=1}^{n}\left(\left(\mu_{i k}\right)^{w} * X_{i j}\right)}{\sum_{i=1}^{n}\left(\mu_{i k}\right)^{w}}
$$

5) Hitung fungsi objektif pada iterasi ke- $t, P_{t}$

$$
P_{t}=\sum_{i=1}^{n} \sum_{k=1}^{c}\left(\left[\sum_{j=1}^{m}\left(X_{i j}-V_{k j}\right)^{2}\right]\left(\mu_{i k}\right)^{w}\right)
$$

6) Hitung perubahan matriks partisi

$$
\mu_{i k}=\frac{\left[\sum_{j=1}^{m}\left(X_{i j}-V_{k j}\right)^{2}\right]^{\frac{-1}{w-1}}}{\sum_{k=1}^{c}\left[\sum_{j=1}^{m}\left(X_{i j}-V_{k j}\right)^{2}\right]^{\frac{-1}{w-1}}}
$$

dengan: $i=1,2, \cdots, n$ dan $k=1,2, \cdots, c$

7) Cek kondisi berhenti

- Jika: $(|P t-P t-1|<\xi)$ atau $(t>$ Maxlter) maka berhenti;

- Jika tidak: $t=t+1$, ulangi langkah ke-4.

\section{Hasil dan Pembahasan}

\subsection{Hasil Penelitian}

Penelitian ini dilakukan pada mahasiswa Jurusan Matematika angkatan 2013 di Fakultas Matematika dan Ilmu Pengetahuan Alam Universitas Pattimura Ambon. Data yang digunakan adalah data mahasiswa yang sudah mendapatkan beasiswa dan yang tidak mendapat beasiswa. Variabel yang digunakan untuk menentukan penerimaan beasiswa menggunakan algoritma Fuzzy C-Means adalah sebagai berikut:
1) $X_{i 1}=$ Semester;
2) $X_{i 2}=$ IPK;
3) $X_{i 3}=$ Penghasilan total orang tua;
4) $X_{i 4}=$ Jumlah tanggungan orang tua;
5) $X_{i 5}=$ Alat transportasi.

Jumlah data sebanyak 14 mahasiswa dengan data ke- $i(i=1,2, \cdots, 14)$. Dari kriteria yang ditentukan dibuat suatu tingkat kepentingan kriteria berdasarkan nilai bobot yang telah ditentukan dalam bilangan fuzzy. Rating kecocokan setiap alternatif pada setiap kriteria sebagai berikut:
1) $\quad$ Rendah $(\mathrm{R})=0$
2) Cukup (C) $=0.5$
3) Tinggi $(\mathrm{T})=1$ 
Nilai bobot dari setiap variabel ditentukan dalam bilangan fuzzy. Hasil perhitungan dilakukan berdasarkan langkah-langkah pada algoritma FCM. Langkah yang pertama yaitu memasukan data yang akan di-cluster ke dalam matriks $X$ sebagai berikut:

$$
X=\left|\begin{array}{ccccc}
1 & 0,5 & 0,5 & 1 & 0,5 \\
1 & 0,5 & 0,5 & 1 & 0 \\
1 & 0,5 & 0 & 1 & 0,5 \\
1 & 1 & 0 & 0,5 & 0,5 \\
1 & 0 & 1 & 0,5 & 0,5 \\
1 & 0,5 & 0 & 1 & 0,5 \\
1 & 0 & 0,5 & 1 & 0,5 \\
1 & 0 & 0 & 0 & 0,5 \\
1 & 1 & 0 & 0 & 0,5 \\
0 & 0,5 & 1 & 1 & 0,5 \\
1 & 0,5 & 0,5 & 1 & 0,5 \\
1 & 0,5 & 1 & 1 & 0,5 \\
1 & 0,5 & 1 & 1 & 0,5 \\
0 & 0 & 0,5 & 0,5 & 0,5
\end{array}\right|
$$

Data yang dimasukan pada matriks $X$ di atas adalah data yang sudah diberi bobot berdasarkan variabelvariabel penelitian.

Pada langkah kedua adalah menentukan parameter awal yang akan digunakan untuk menyelesaikan masalah dengan algoritma Fuzzy C-Means. Parameter-parameter tersebut adalah banyak cluster $(c=2)$, pangkat $(w=2)$, maksimum iterasi (MaxIter $=50)$, eror terkecil yang diharapkan $(\xi=0,01)$, fungsi objektif awal $\left(P_{0}=0\right)$, dan iterasi awal $(t=1)$. Banyaknya cluster yang ditentukan ada dua yaitu cluster untuk yang layak menerima besiswa dan cluster untuk yang tidak layak menerima beasiswa.

Langkah ketiga akan dibangkitkan matriks $U$ dengan komponen $\mu_{i k}, i=14 ; k=2$, nilai $\mu_{i k}$ ditentukan secara acak dengan syarat jumlah nilai elemen matriks dari kolom dalam setiap baris harus 1 . Matriks $U$ yang terbentuk (secara random) adalah sebagai berikut:

$$
U=\left|\begin{array}{ll}
0,820 & 0,180 \\
0,677 & 0,323 \\
0,327 & 0,673 \\
0,166 & 0,834 \\
0,727 & 0,273 \\
0,327 & 0,673 \\
0,774 & 0,226 \\
0,304 & 0,696 \\
0,222 & 0,778 \\
0,674 & 0,326 \\
0,820 & 0,180 \\
0,875 & 0,125 \\
0,875 & 0,125 \\
0,542 & 0,458
\end{array}\right|
$$

Matriks $U$ yang sudah terbentuk akan digunakan untuk menghitung pusat cluster pada langkah selanjutnya. Langkah keempat akan dihitung pusat cluster. Berikut adalah hasil perhitungan pusat cluster dengan rumus sehingga menghasilkan pusat cluster 1 dan pusat cluster 2 yaitu sebagai berikut: 
Tabel 1. Pusat Cluster Awal

\begin{tabular}{|c|c|}
\hline$\mu_{i 1}^{w}$ & $\mu_{i 2}^{w}$ \\
\hline 0.6724 & 0.0324 \\
\hline 0.458329 & 0.104329 \\
\hline 0.106929 & 0.452929 \\
\hline 0.027556 & 0.695556 \\
\hline 0.528529 & 0.074529 \\
\hline 0.106929 & 0.452929 \\
\hline 0.599076 & 0.051076 \\
\hline 0.092416 & 0.484416 \\
\hline 0.049284 & 0.605284 \\
\hline 0.454276 & 0.106276 \\
\hline 0.6724 & 0.0324 \\
\hline 0.765625 & 0.015625 \\
\hline 0.765625 & 0.015625 \\
\hline 0.293764 & 0.209764 \\
\hline$\sum \mathbf{5 . 5 9 3 1 3 8}$ & $\sum 3.333138$ \\
\hline & \\
\hline
\end{tabular}

Pada Tabel $1 \mathrm{di}$ atas hasilnya diperoleh dari hasil pangkat dari matriks $U$ pada setiap kolomnya dengan $w=2$ dan akan dipakai pada perkalian dengan matriks $X$. Nilai dari $\Sigma$ adalah hasil penjumlahan dari setiap kolomnya dan akan dipakai untuk menghitung hasil pusat cluster 1 dan 2.

Pada tabel dibawah ini merupakan hasil perkalian antara kolom $\mu_{i 1}^{w}$ pada Tabel 1 dengan setiap kolom pada matriks $X$ dan nilai dari $\Sigma$ adalah hasil penjumlahan untuk setiap kolomnya dan nilai-nilai dari $\Sigma$ tersebut akan dipakai dalam menghitung hasil pusat cluster 1.

Tabel 2. Perkalian antara Kolom $\mu_{i 1}^{w}$ dengan Setiap Kolom Matriks $X$

\begin{tabular}{|c|c|c|c|c|c|}
\hline Data ke- & $\boldsymbol{\mu}_{\boldsymbol{i 1}}^{\boldsymbol{w}} * \boldsymbol{X}_{\boldsymbol{i 1}}$ & $\boldsymbol{\mu}_{\boldsymbol{i} \mathbf{1}}^{\boldsymbol{w}} * \boldsymbol{X}_{\boldsymbol{i} \mathbf{2}}$ & $\boldsymbol{\mu}_{\boldsymbol{i} \mathbf{1}}^{\boldsymbol{w}} * \boldsymbol{X}_{\boldsymbol{i} \mathbf{3}}$ & $\boldsymbol{\mu}_{\boldsymbol{i} \mathbf{1}}^{\boldsymbol{w}} * \boldsymbol{X}_{\boldsymbol{i} \mathbf{4}}$ & $\boldsymbol{\mu}_{\boldsymbol{i \mathbf { 1 }}}^{\boldsymbol{w}} * \boldsymbol{X}_{\boldsymbol{i} \mathbf{5}}$ \\
\hline 1 & 0,672 & 0,336 & 0,336 & 0,672 & 0,336 \\
\hline 2 & 0,458 & 0,229 & 0,229 & 0,458 & 0 \\
\hline 3 & 0,107 & 0,053 & 0 & 0,107 & 0,053 \\
\hline 4 & 0,028 & 0,028 & 0 & 0,014 & 0,014 \\
\hline 5 & 0,529 & 0 & 0,529 & 0,264 & 0,264 \\
\hline 6 & 0,107 & 0,053 & 0 & 0,107 & 0,053 \\
\hline 7 & 0,599 & 0 & 0,3 & 0,599 & 0,3 \\
\hline 8 & 0,092 & 0 & 0 & 0 & 0,046 \\
\hline 9 & 0,049 & 0,049 & 0 & 0 & 0,025 \\
\hline 10 & 0 & 0,227 & 0,454 & 0,454 & 0,227 \\
\hline 11 & 0,672 & 0,336 & 0,336 & 0,672 & 0,336 \\
\hline 12 & 0,766 & 0,383 & 0,766 & 0,766 & 0,383 \\
\hline 13 & 0,766 & 0,383 & 0,766 & 0,766 & 0,383 \\
\hline 14 & 0 & 0 & 0,147 & 0,147 & 0,147 \\
\hline $\boldsymbol{\Sigma}$ & $\mathbf{4 , 8 4 5}$ & $\mathbf{2 , 0 7 8}$ & $\mathbf{3 , 8 6 2}$ & $\mathbf{5 , 0 2 7}$ & $\mathbf{2 , 5 6 7}$ \\
\hline
\end{tabular}

Selanjutnya pada Tabel 3 diberikan hasil perkalian antara kolom $\mu_{i 2}^{w}$ pada Tabel 1 dengan setiap kolom pada matriks $X$ dan nilai dari $\Sigma$ adalah hasil penjumlahan untuk setiap kolomnya dan nilai-nilai dari $\Sigma$ tersebut akan dipakai untuk menghitung hasil pusat cluster 2. 
Tabel 3. Perkalian antara Kolom $\mu_{i 2}{ }^{w}$ dengan Setiap Kolom Matriks $X$

\begin{tabular}{|c|c|c|c|c|c|}
\hline Data ke- & $\mu_{i 2}^{w} * X_{i 1}$ & $\mu_{i 2}^{w} * X_{i 2}$ & $\mu_{i 2}^{w} * X_{i 3}$ & $\mu_{i 2}^{w} * X_{i 4}$ & $\mu_{i 2}^{w} * X_{i 5}$ \\
\hline 1 & 0,032 & 0,016 & 0,016 & 0,032 & 0,016 \\
\hline 2 & 0,104 & 0,052 & 0,052 & 0,104 & 0 \\
\hline 3 & 0,453 & 0,226 & 0 & 0,453 & 0,226 \\
\hline 4 & 0,696 & 0,696 & 0 & 0,348 & 0,348 \\
\hline 5 & 0,075 & 0 & 0,075 & 0,037 & 0,037 \\
\hline 6 & 0,453 & 0,226 & 0 & 0,453 & 0,226 \\
\hline 7 & 0,051 & 0 & 0,026 & 0,051 & 0,026 \\
\hline 8 & 0,484 & 0 & 0 & 0 & 0,242 \\
\hline 9 & 0,605 & 0,605 & 0 & 0 & 0,303 \\
\hline 10 & 0 & 0,053 & 0,106 & 0,106 & 0,053 \\
\hline 11 & 0,032 & 0,016 & 0,016 & 0,032 & 0,016 \\
\hline 12 & 0,016 & 0,008 & 0,016 & 0,016 & 0,008 \\
\hline 13 & 0,016 & 0,008 & 0,016 & 0,016 & 0,008 \\
\hline 14 & 0 & 0 & 0,105 & 0,105 & 0,105 \\
\hline$\Sigma$ & 3,017 & 1,907 & 0,427 & 1,754 & 1,614 \\
\hline
\end{tabular}

Selanjutnya pada Tabel 4 diberikan hasil perhitungan pusat cluster 1 dan pusat cluster 2. Hasil untuk cluster 1 pada baris pertama diperoleh dari baris pada hasil penjumlahan setiap $\Sigma$ pada Tabel 2 dibagi dengan nilai $\Sigma$ pada kolom $\mu_{i 1}^{w}$ dan untuk cluster 2 pada baris kedua hasilnya diperoleh dari baris pada hasil penjumlahan setiap $\Sigma$ pada Tabel 3 dibagi dengan nilai $\Sigma$ pada kolom $\mu_{i 2}^{w}$

Tabel 4. Hasil Pusat Cluster Iterasi 1

\begin{tabular}{|c|l|l|l|l|l|}
\hline $\boldsymbol{V}_{\boldsymbol{k} \boldsymbol{j}}$ & $\mathbf{1}$ & $\mathbf{2}$ & $\mathbf{3}$ & $\mathbf{4}$ & $\mathbf{5}$ \\
\hline 1 & 0,866 & 0,372 & 0,690 & 0,899 & 0,459 \\
\hline 2 & 0,905 & 0,572 & 0,128 & 0,526 & 0,484 \\
\hline
\end{tabular}

Selanjutnya akan digunakan hasil pusat cluster pada tabel di atas untuk mencari nilai fungsi objektif pada langkah selanjutnya. Langkah kelima adalah menghitung nilai fungsi objektif $\left(P_{1}\right)$ dengan rumus (lihat 1.4. Algoritma Fuzzy C-Means).

Pada Tabel 5, kolom $C_{1}$ hasilnya diperoleh dari setiap baris pada matriks $X$ dikurangi dengan cluster 1 pada Tabel 4 kemudian dipangkatkan 2. Selanjutnya hasil penjumlahan setiap baris pada kolom $C_{1}$ dapat dilihat pada kolom $\sum \boldsymbol{C}_{\mathbf{1}}$. Pada kolom $\sum \boldsymbol{C}_{\mathbf{1}} * \mu_{i 1}^{w}$ hasilnya diperoleh dari perkalian antara kolom $\sum \boldsymbol{C}_{\mathbf{1}}$ dengan kolom $\mu_{i 1}^{w}$ pada Tabel 1 . Hasil pada kolom $\sum \boldsymbol{C}_{\mathbf{1}}$ akan dipakai untuk mencari matriks $U$ baru dan hasil pada kolom $\sum \boldsymbol{C}_{\mathbf{1}} * \mu_{i 1}^{w}$ akan dipakai untuk menghitung nilai fungsi objektif $\left(P_{1}\right)$.

Pada Tabel 6 kolom $C_{2}$ hasilnya diperoleh dari setiap baris pada matriks $X$ dikurangi dengan cluster 2 pada Tabel 4 kemudian dipangkatkan 2. Selanjutnya hasil penjumlahan setiap baris pada kolom $C_{2}$ dapat dilihat pada kolom $\sum \boldsymbol{C}_{\mathbf{2}}$ kemudian pada kolom $\sum \boldsymbol{C}_{\mathbf{2}} * \mu_{i 2}^{w}$ hasilnya diperoleh dari perkalian antara kolom $\sum \boldsymbol{C}_{\mathbf{2}}$ dengan kolom $\mu_{i 2}^{w}$ pada Tabel 1 . Hasil pada kolom $\sum \boldsymbol{C}_{\mathbf{2}}$ akan dipakai untuk mencari matriks $U$ baru dan hasil pada kolom $\sum \boldsymbol{C}_{\mathbf{2}} * \mu_{i 2}^{w}$ akan dipakai untuk menghitung nilai fungsi objektif $\left(P_{1}\right)$. 
Tabel 5. Hasil Perhitungan $C_{1}$

\begin{tabular}{|c|c|c|c|c|c|c|c|}
\hline \multirow{2}{*}{$\begin{array}{c}\text { Data } \\
\text { ke- }\end{array}$} & \multicolumn{5}{|c|}{$\mathrm{C}_{1}$} & \multirow{2}{*}{$\Sigma C_{1}$} & \multirow{2}{*}{$\sum C_{1} * \mu_{i 1}^{w}$} \\
\hline & $\left(X_{i 1}-V_{i 1}\right)^{2}$ & $\left(X_{i 2}-V_{i 1}\right)^{2}$ & $\left(X_{i 3}-V_{i 1}\right)^{2}$ & $\left(X_{i 4}-V_{i 1}\right)^{2}$ & $\left(X_{i 5}-V_{i 1}\right)^{2}$ & & \\
\hline 1 & 0,018 & 0,017 & 0,036 & 0,01 & 0,002 & 0,083 & 0,056 \\
\hline 2 & 0,018 & 0,017 & 0,036 & 0,01 & 0,211 & 0,292 & 0,134 \\
\hline 3 & 0,018 & 0,017 & 0,477 & 0,01 & 0,002 & 0,523 & 0,056 \\
\hline 4 & 0,018 & 0,395 & 0,477 & 0,159 & 0,002 & 1,05 & 0,029 \\
\hline 5 & 0,018 & 0,138 & 0,096 & 0,159 & 0,002 & 0,412 & 0,218 \\
\hline 6 & 0,018 & 0,017 & 0,477 & 0,01 & 0,002 & 0,523 & 0,056 \\
\hline 7 & 0,018 & 0,138 & 0,036 & 0,01 & 0,002 & 0,204 & 0,122 \\
\hline 8 & 0,018 & 0,138 & 0,477 & 0,808 & 0,002 & 1,442 & 0,133 \\
\hline 9 & 0,018 & 0,395 & 0,477 & 0,808 & 0,002 & 1,699 & 0,084 \\
\hline 10 & 0,75 & 0,017 & 0,096 & 0,01 & 0,002 & $\mathbf{0 , 8 7 5}$ & 0,397 \\
\hline 11 & 0,018 & 0,017 & 0,036 & 0,01 & 0,002 & 0,083 & 0,056 \\
\hline 12 & 0,018 & 0,017 & 0,096 & 0,01 & 0,002 & 0,142 & 0,109 \\
\hline 13 & 0,018 & 0,017 & 0,096 & 0,01 & 0,002 & 0,142 & 0,109 \\
\hline 14 & 0,75 & 0,138 & 0,036 & 0,159 & 0,002 & 1,085 & 0,319 \\
\hline
\end{tabular}

Tabel 6. Hasil Perhitungan $C_{2}$

\begin{tabular}{|c|c|c|c|c|c|c|c|}
\hline \multirow{2}{*}{$\begin{array}{c}\text { Data } \\
\text { ke- }\end{array}$} & \multicolumn{5}{|c|}{$C_{2}$} & \multirow{2}{*}{$\Sigma C_{2}$} & \multirow{2}{*}{$\sum \boldsymbol{C}_{2} * \boldsymbol{\mu}_{i 2}^{w}$} \\
\hline & $\left(X_{i 1}-V_{i 2}\right)^{2}$ & $\left(X_{i 2}-V_{i 2}\right)^{2}$ & $\left(X_{i 3}-V_{i 2}\right)^{2}$ & $\left(X_{i 4}-V_{i 2}\right)^{2}$ & $\left(X_{i 5}-V_{i 2}\right)^{2}$ & & \\
\hline 1 & 0,018 & 0,017 & 0,036 & 0,01 & 0,002 & 0,083 & 0,056 \\
\hline 2 & 0,018 & 0,017 & 0,036 & 0,01 & 0,211 & 0,292 & 0,134 \\
\hline 3 & 0,018 & 0,017 & 0,477 & 0,01 & 0,002 & 0,523 & 0,056 \\
\hline 4 & 0,018 & 0,395 & 0,477 & 0,159 & 0,002 & 1,05 & 0,029 \\
\hline 5 & 0,018 & 0,138 & 0,096 & 0,159 & 0,002 & 0,412 & 0,218 \\
\hline 6 & 0,018 & 0,017 & 0,477 & 0,01 & 0,002 & 0,523 & 0,056 \\
\hline 7 & 0,018 & 0,138 & 0,036 & 0,01 & 0,002 & 0,204 & 0,122 \\
\hline 8 & 0,018 & 0,138 & 0,477 & 0,808 & 0,002 & 1,442 & 0,133 \\
\hline 9 & 0,018 & 0,395 & 0,477 & 0,808 & 0,002 & 1,699 & 0,084 \\
\hline 10 & 0,75 & 0,017 & 0,096 & 0,01 & 0,002 & 0,875 & 0,397 \\
\hline 11 & 0,018 & 0,017 & 0,036 & 0,01 & 0,002 & 0,083 & 0,056 \\
\hline 12 & 0,018 & 0,017 & 0,096 & 0,01 & 0,002 & 0,142 & 0,109 \\
\hline 13 & 0,018 & 0,017 & 0,096 & 0,01 & 0,002 & 0,142 & 0,109 \\
\hline 14 & 0,75 & 0,138 & 0,036 & 0,159 & 0,002 & 1,085 & 0,319 \\
\hline
\end{tabular}

Selanjutnya pada Tabel 7 diberikan hasil perhitungan fungsi objektif untuk iterasi pertama. Hasilnya diperoleh dari penjumlahan antara kolom $\sum C_{1} * \mu_{i 1}^{w}$ pada Tabel 4.5 dengan kolom $\sum C_{2} * \mu_{i 2}^{w}$ pada Tabel 6 kemudian hasil penjumlahannya pada nilai $\sum$ yang akan menjadi nilai dari $P_{1}$ yaitu 3,552 . 
Tabel 7. Hasil Perhitungan Fungsi Objektif $\left(P_{1}\right)$

\begin{tabular}{|c|c|}
\hline Data ke- & $\sum \boldsymbol{C}_{\mathbf{1}} * \boldsymbol{\mu}_{\boldsymbol{i} \mathbf{w}}^{\boldsymbol{w}}+\sum \boldsymbol{C}_{\mathbf{2}} * \boldsymbol{\mu}_{\boldsymbol{i} \mathbf{w}}^{\boldsymbol{w}}$ \\
\hline 1 & 0,068 \\
\hline 2 & 0,197 \\
\hline 3 & 0,172 \\
\hline 4 & 0,175 \\
\hline 5 & 0,3 \\
\hline 6 & 0,172 \\
\hline 7 & 0,158 \\
\hline 8 & 0,438 \\
\hline 9 & 0,378 \\
\hline 10 & 0,59 \\
\hline 11 & 0,068 \\
\hline 12 & 0,124 \\
\hline 13 & 0,124 \\
\hline 14 & 0,589 \\
\hline$\sum$ & $\mathbf{3 . 5 5 2}$ \\
\hline
\end{tabular}

Langkah keenam akan dicari matriks $U$ baru dengan rumus (lihat 1.4. Algoritma Fuzzy C-Means). Untuk kolom pertama hasilnya diperoleh dari kolom $\boldsymbol{\Sigma} \boldsymbol{C}_{\mathbf{1}}$ dibagi dengan penjumlahan antara kolom $\boldsymbol{\Sigma} \boldsymbol{C}_{\mathbf{1}}$ dengan kolom $\boldsymbol{\Sigma} \boldsymbol{C}_{\mathbf{2}}$ dan untuk kolom kedua hasilnya diperoleh dari kolom $\boldsymbol{\Sigma} \boldsymbol{C}_{\mathbf{2}}$ dibagi dengan penjumlahan antara kolom $\boldsymbol{\Sigma} \boldsymbol{C}_{\mathbf{1}}$ dengan kolom $\boldsymbol{\Sigma} \boldsymbol{C}_{\mathbf{2}}$. Maka diperoleh matriks $U$ dengan derajat keanggotaan baru sebagai berikut:

$$
U=\left|\begin{array}{ll}
0,180 & 0,820 \\
0,323 & 0,677 \\
0,627 & 0,373 \\
0,834 & 0,166 \\
0,273 & 0,727 \\
0,671 & 0,329 \\
0,226 & 0,774 \\
0,696 & 0,304 \\
0,778 & 0,222 \\
0,326 & 0,674 \\
0,180 & 0,820 \\
0,125 & 0,875 \\
0,125 & 0,875 \\
0,458 & 0,542
\end{array}\right|
$$

Pada langkah ketujuh (langkah terakhir) akan diperiksa kondisi berhenti dimana nilai dari $\left|P_{t}-P_{t-1}\right| \xi$. Karena $\left|P_{1}-P_{1-1}\right|<\xi$ yaitu 3,552 $>0,01$ maka diulangi dari langkah 4 sampai pada iterasi terakhir dimana kondisi telah berhenti dengan menggunakan matriks $U$ baru yang sudah diperoleh pada langkah sebelumnya.

Berikut adalah hasil pengelompokan berdasarkan derajat keanggotaan pada iterasi terakhir yaitu iterasi ke-11 dengan nilai $\left|P_{11}-P_{10}\right|$ yaitu $|3,55165857-3,55165857|<\xi$. Dari hasil perhitungan pada Tabel 8 
maka dapat disimpulkan bahwa anggota-anggota yang berada pada cluster 2 dengan nilai cluster yang lebih besar dari nilai cluster pada cluster 1 layak untuk menerima beasiswa yaitu sebanyak 9 orang.

Tabel 8. Hasil Clustering

\begin{tabular}{|c|c|c|c|}
\hline \multirow{2}{*}{ Nama } & \multicolumn{2}{|c|}{ Data Keanggotaan } & \multirow{2}{*}{ Cluster } \\
\cline { 2 - 3 } & Cluster 1 & Cluster 2 & \\
\hline 1 & 0.177 & 0.823 & 2 \\
\hline 2 & 0.321 & 0.679 & 2 \\
\hline 3 & 0.669 & 0.331 & 1 \\
\hline 4 & 0.834 & 0.166 & 1 \\
\hline 5 & 0.274 & 0.726 & 2 \\
\hline 6 & 0.669 & 0.331 & 1 \\
\hline 7 & 0.225 & 0.775 & 2 \\
\hline 8 & 0.697 & 0.303 & 1 \\
\hline 9 & 0.779 & 0.221 & 1 \\
\hline 10 & 0.326 & 0.674 & 2 \\
\hline 11 & 0.177 & 0.823 & 2 \\
\hline 12 & 0.124 & 0.876 & 2 \\
\hline 13 & 0.124 & 0.876 & 2 \\
\hline 14 & 0.458 & 0.542 & 2 \\
\hline
\end{tabular}

Dari Tabel 9 dapat dilihat kecocokan hasil FCM dengan target sebesar 50\%.

Tabel 9. Perbandingan Hasil FCM dengan Target

\begin{tabular}{|c|r|r|r|l|l|}
\hline \multirow{2}{*}{ Nama } & \multicolumn{2}{|c|}{ Data Keanggotaan } & \multirow{2}{*}{ Cluster } & \multirow{2}{*}{ Hasil FCM } & \multirow{2}{*}{ Target } \\
\cline { 2 - 5 } & Cluster 1 & \multicolumn{1}{l}{ Cluster 2} & & & Menerima \\
\hline 1 & 0.177 & 0.823 & 2 & Menerima & Menerima \\
\hline 2 & 0.321 & 0.679 & 2 & Menerima & Menerima \\
\hline 3 & 0.669 & 0.331 & 1 & Tidak Menerima & Menerima \\
\hline 4 & 0.834 & 0.166 & 1 & Tidak Menerima & Menerima \\
\hline 5 & 0.274 & 0.726 & 2 & Menerima & Menerima \\
\hline 6 & 0.669 & 0.331 & 1 & Tidak Menerima & Menerima \\
\hline 7 & 0.225 & 0.775 & 2 & Menerima & Menerima \\
\hline 8 & 0.697 & 0.303 & 1 & Tidak Menerima & Menerima \\
\hline 9 & 0.779 & 0.221 & 1 & Tidak Menerima & Tidak Menerima \\
\hline 10 & 0.326 & 0.674 & 2 & Menerima & Menerima \\
\hline 11 & 0.177 & 0.823 & 2 & Menerima & Menerima \\
\hline 12 & 0.124 & 0.876 & 2 & Menerima & Menerima \\
\hline 13 & 0.124 & 0.876 & 2 & Menerima & Tidak Menerima \\
\hline 14 & 0.458 & 0.542 & 2 & Menerima & \\
\hline
\end{tabular}

\section{Kesimpulan}

Berdasarkan pembahasan pada bagian sebelumnya, maka dapat disimpulkan bahwa:

1) Dari 14 data mahasiswa yang diperoleh, setelah diteliti dengan menggunakan metode FCM diperoleh 9 mahasiswa yang layak untuk menerima beasiswa.

2) Seteleh dibandingkan diperoleh $50 \%$ kecocokan hasil FCM dengan target, maka metode ini dapat dipertimbangkan untuk dipakai dalam penentuan kelayakan penerimaan beasiswa. 


\section{Daftar Pustaka}

[1] D. F. Putranto, "Implementasi Sistem Perekomendasian Penerima Beasiswa dengan Analytical Hierarchy Process,” Teknik Informatika, ITS, Surabaya, 2016.

[2] J. Bezdek, Pattern Recognition with Fuzzy Objective Function Algorithm, New York: Plenum Press, 1981.

[3] S. Kusumadewi and H. Purnomo, Aplikasi Logika Fuzzy untuk pendukung keputusan, Yogyakarta: Graha Ilmu, 2004.

[4] I. Surbakti , Sistem Pendukung Keputusan (Decision Support System), Yogyakarta: Graha Ilmu, 2002.

[5] N. Gelley and J. Roger, Fuzzy Logic Toolbox, USA: Mathwork Inc., 2000. 
